\title{
画像通信による育児支援システムの検討 \\ On tele-consultation for childcare using image communication
}

\author{
○鈴木 真 ${ }^{1}$, 片岡幸代 ${ }^{2}$ \\ 1. 東京電機大学 情報環境学部, 2. (株) HALCA ラボ \\ OSUZUKI Makoto ${ }^{1}$ and KATAOKA Sachiyo ${ }^{2}$
}

1. School of Information Environment, Tokyo Denki University 2. HALCA Laboratory

\section{1. はじめに}

少子高齢化の進む中、わが国の将来を担う世代を育てるため、 より良い育児をサポートする環境・システムづくりがますます重要 となっている.

その一つとして、育児不安を解消するための相談システムがあ る. 核家族化などのライフスタイルの変化から、周囲に相談できる 人が少なくなったり、若いらちに子どもと接する機会がないまま親 になる人が増えたりと、育児に関して不安や悩みを持つ人は多い。 こうしたケースに対して、専門家が応対して状況を把握しアドバイ スを提供することが有効である.

しかし、小児科医など相談に対応できる専門家は全国的に不 足してきており、かつ都市部に集中しがちで地域による格差が大 きく、直接の対面での相談だけでは十分なサポートができていな い. 遠隔での相談では、これまでのところ電話が主な手段である が、音声のみのやりとりでは、相談者側の状況がわかりにくく、ア ドバイスも細かいところまでは伝えにくい.

我々は、こうした状況を解決すべく、インターネットを介して音 声だけでなく画像もやりとりすることで、より効果的な育児相談を 行えるようなシステムの実現を目指している. 本報では、必要とな る情報にはどのようなものがあるかを検討し、実験システムの構築 を試みたので報告する.

\section{2. やりとりすべき情報の検討}

I T 技術の進歩・普及により、現在ではパソコンとU S B カメラを用いて、ビデオチャット（テレビ電話）を容易に実 現できるようになった。こうした安価なシステムは、既に医 療や福祉目的で使われ始めているが、ここでは、より効果的 な遠隔相談システムとすべく、相談者と専門家の間で、どの ような情報をやりとりすべきかを検討した。

まず専門家が、相談者側の親子の状況を知るためには、映 像と音声が有効である。ただし、的確に状況を把握するため には、子どもと親、あるいは全景とクローズアップなど、状 況に応じた複数の視点から観察しなくてはならない.そこで、 専門家が受け取る映像・音声情報について、少なくとも2 ヤンネルが必要であり、さらに専門家側から撮影範囲を操作 できるようにするものとした.

次に相談者側が受け取るべき情報について検討した結果、 専門家側との会話だけでなく、様々な育児情報コンテンツを 見ることができるようになっていることが望ましいと考えた。 ここで、この育児支援に役立てる情報は、パソコンによって 提示されるため、文章や静止画などの静的な内容だけでなく、 動きを持ったコンテンツも提供可能である．そこで、専門家 が相談者に提供する情報について、オンライン動画や Flash アニメーションなども含めた、多様な種類のコンテンツを扱 えるようにするものとした.

以上の、相談者と専門家側での情報のやりとりについて検 討した結果を、Fig.1 にまとめた。ここに示されたように、 通常のビデオチャットのような映像と音声の単純な双方向通 信では、我々が目指している効果的な育児相談システムは実
現できず、新たに構築しなくてはならない.

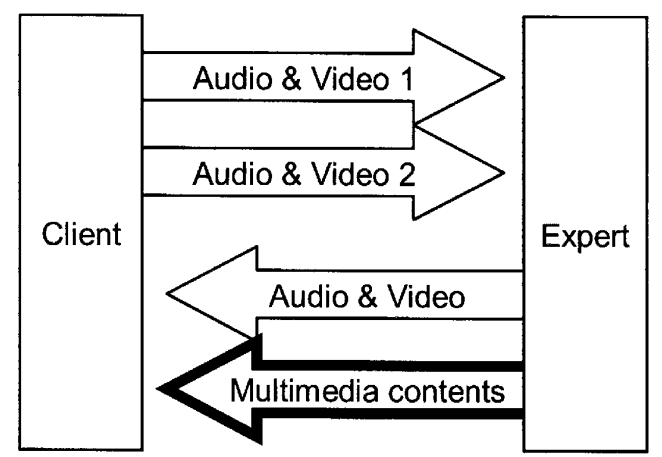

Fig. 1 Information for childcare consultation

\section{3. 実験的システムの粠築}

構築にあたって、相談者側での導入が簡易になることを念頭に 置いた. まず専門家が必要とする映像・音声を得る手段として、パ ン・チルト・ズームの遠隔操作機能を備えたネットワークカメラ(プ ラネックス、CS-WMV03G)を用いた.これは、撮影範囲の変更を 見ている専門家側から行えるため、相談者側での操作が不要で ある. 構築したシステムでは2台のネットワークカメラを用い、専門 家側から複数の映像を同時に得られるようにした。

次に専門家側からの情報提供は、WEBサーバ(Apache1.3) で行った. 提示したいコンテンツは、すべて予め用意しておくこと を前提に、相談時には適切なコンテンツのみが表示されるよう、 専門家の操作によって、サーバ上のHTMLファイルを変更するこ ととした.これにより、相談者側については、通常のWEBブラウザ を使って、提供された情報を閲覧できるため、特別なソフトウェア を導入する必要がない. 専門家側では、Visual Basic2005 で開 発した専用ソフトウェアを導入、操作することとした。

さらに、専門家自身の映像・音声は、ストリーミング形式で送信 することで、上記の育児情報コンテンツとWEBブラウザ上でシー ムレスに表示されるようにした. 具体的には、USB カメラと Flash Media Encoder2、Flash Media Server2 を利用して、ストリーミ ング配信を行った.

構築したシステムでは、一般的なブロードバンドのネットワーク 状況を想定し、ネットワークカメラからの映像はサイズ $320 \times 240$ 、 フレームレート $30 \mathrm{fps}$ 、 ストリーミングは映像サイズ $320 \times 240$ 、フ レームレート $10 \mathrm{fps}$ で配信されるよう設定した。

\section{4. おわりに}

現在、専門家側のサーバに要求される性能、ネットワーク負荷 がおよぼす影響、実際の育児相談を想定したシステムの動作な どについて検討を進めている.これまでの所、専門家側での映像 表示や、相談者側での情報提示について、固定的な画面設計で は不十分であることが分かった。

今後は、その場の状況に合わせた見やすい画面づくりと、操作 性向上を目指し、改良と試用評価を進めていく. 